\title{
Gün Işığı Yönlendirme Sistemleri
}

\author{
Muhammed Engin ÇifTçi $1 *$ (D), Ümit Turgay ARPACIOĞLU ${ }^{2}$ \\ ORCID 1: 0000-0002-7945-1677 \\ ORCID 2: 0000-0001-8858-7499 \\ ${ }^{1}$ Mimar Sinan Güzel Sanatlar Üniversitesi, Fen Bilimleri Enstitüsü, Yapı Fiziği ve Malzemesi Ana Bilim Dalı, \\ 34427, Istanbul, Türkiye \\ ${ }^{2}$ Mimar Sinan Güzel Sanatlar Üniversitesi, Mimarlık Fakültesi, Yapı Fiziği ve Malzemesi Ana Bilim Dalı, 34427, \\ istanbul, Türkiye \\ *e-mail: menginciftci@gmail.com
}

\section{Öz}

Sürdürülebilir mimarlık kavramı ile yenilenebilir enerji kaynaklarının bina yaşam döngüsü içerisinde yer almaya başladığı görülür. Enerji tasarrufu ve kullanılan doğal kaynaklardan elde edilen enerjinin verimli şekilde kullanılması açısında yenilenebilir enerji kaynakları önem taşımaktadır. Tasarım süreci içerisinde ışığın hacimlerde etkin şekilde kullanılması fikri ile beraber hem enerji tasarrufu sağlaması hem de mekân içerisindeki konfor şartlarının oluşmasını amaçlanmıştır. Teknolojinin gelişmesiyle devam eden süreçte insanların konfor yönünden talepleri artmıştır. Sürdürülebilir mimarlık ilkeleri doğrultusunda iklimsel ve görsel konfor şartlarını sağlamak, enerji tüketimini azaltmak ve çevreye verilen zararı minimuma indirmek amacıyla gün ışığı yönlendirme sistemleri geliştirilmeye başlanmıştır. Bu çalışmada 19.yy'da geliştirilmeye başlanan gün ışı̆̆ıönlendirme sistemlerinin iş mekânlardaki aydınlatma ve konfor ihtiyacının giderilmesine bulunduğu katkılar ve bu sistemlerin günümüz mimarı̆ı̆ında kullanılması durumunda ne gibi faydaları olabileceğine ışık tutmak istenmiştir.

Anahtar Kelimeler: Gün ışığı, gün ışığı yönlendirme sistemleri, iç mekân

\section{Daylight Guidance Systems}

\begin{abstract}
Sustainable architecture concept and renewable energy sources begin to take places in to the building life cycle. Renewable energy sources are critical in terms of energy saving and using efficient of useable natural energy sources. With the idea of using the light in spaces actively, it is intended to save energy and create a comfortable space. During the ongoing process with the advancement of technology, people's demand for comfort has increased. Daylight guidance systems developed to provide the climatic and visual comfort conditions, reduce the energy consumption and minimizing the damage dealt to the environment. This study aims to show the contribution of the daylight guidance systems that are being started to develop in the 19th century, to meet the need for interior lighting and comfort. It also shows the possible benefits of these systems in the case of usage in today's architecture.
\end{abstract}

Keywords: Daylight, daylight guidance systems, interior

Atıf/Citation: Çiftçi, M. E, Arpacıoğlu, Ü. T. (2021). Gün Işığı Yönlendirme Sistemleri. Journal of Architectural Sciences and Applications, 6 (1), 59-76. DOI: 10.30785/mbud.794257 


\section{Giriş}

Endüstri devrimi, makineleşme ve teknolojinin gelişmesine bağlı olarak devam eden süreçte artan enerji ihtiyacına cevap verebilmek için kullanılan fosil yakıtların, yaşadığımız çevreye ve insan sağlığına olan zararlı etkileri insanları gerekli olan enerji ihtiyacının karşılanmasında yenilenebilir enerji kaynaklarına yönlendirmiştir. 20.yy'ın son çeyreğinde meydana gelen petrol krizi sonucunda gelişmiş devletlerin ihtiyaç duyduğu enerji gereksinimini karşılayamaması sonucunda ortaya çıkan problemler yenilenebilir enerji kaynaklarına olan yönelimi hızlandırmış ve bu konunun sadece insanlar tarafından değil devletler tarafından da ele alınmasına neden olmuştur. Dünya genelinde oluşmaya başlayan çevre duyarlılı̆ı bilinci kapsamında sanayi kuruluşları ve konutlar üzerinde yeni kanunlar, yönetmelikler ve standartlar oluşturulmaya başlanmıştır. Çevreye duyarlı bina yapımı ön plana çıkmış ve enerji etkin yapı tasarımları önem kazanmıştır. Bu kapsamda oluşturulan 'Yeşil Bina Sertifika Sistemleri' ile yapılması planlanan mimari projelerin inşaat süreçleri ve yapı ömürleri boyunca çevreye duyarlılıkları değerlendirilmeye çalışılarak yenilenebilir enerji kaynaklarının kullanımı teşvik edilmiştir.

Doğal enerji kaynağı olan güneş, yüzyıllardır doğa ve yeryüzünde yaşayan canlılar en önemli yenilenebilir enerji kaynağı olmuştur. Enerji üretimine ilişkin farklı kaynaklarının bulunmasına kadar ki geçen süre içerinde insanlar güneş odaklı tasarımlar yapmış ve güneşten maksimum düzeyde faydalanmaya çalışmışlardır. Güneş aynı zamanda yapay ışık kaynaklarının bulanmasına kadar geçen sürede, doğal aydınlatma kaynağı olarak görülmüş ve ideal ışık olarak kabul edilmiştir. Isıtma enerjisi olarak kullandığımız güneş enerjisinin, dış ortamda ve iç mekânlarda aydınlatma için harcanılan enerjinin minimuma indirilmesi ve insan sağı̆ğına olan pozitif etkileri bakımından önemli olduğunu görmekteyiz. Aydınlatma konusunda 'Doğal Aydınlatma' olarak adlandırdığımız iç hacimlerde gün ışığı kullanımı ile aydınlatma için harcanılan enerjinin azaltılması ve görsel konfor şartlarının oluşturulması sağlanmaktadır.

Bu çalışma kapsamında binalarda iç hacimlere alınan güneş ışığı miktarının arttırılması, iç hacimlerde gün ışığı kullanımı ile herhangi bir enerji harcanmaksızın aydınlatma ihtiyacı duyulan hacimlerdeki aydınlatma ihtiyacının giderilmesi ve aynı zamanda bu ihtiyacın giderilmesi sırasında hacim içerisindeki konfor şartlarının sağlanmasına yardımcı olan gün ışığı yönlendirme sistemleri irdelenmiştir.

\section{Yöntem}

Çalışma kapsamında hem tasarımcılara yardımcı olabilmek hem de gün ışığı yönlendirme sistemlerinin kullandıkları ışı tipine bağı olarak gösterdikleri davranışları derecelendirebilmek adına "IEA-Daylight In Buildings (Uluslararası Enerji Ajansı-Binalarda Gün Işığı)" yayınında ele alınan ve bütün gün ışığı yönlendirme sistemlerinin değerlendirilmesinde kullanılan 'Dış görüş, Işı̆̆ı hacim içerisine taşıma, Gölgeleme performansı, Homojen aydınlatma, Kamaşmadan koruma ve Yapay aydınlatmadan tasarruf' olmak üzere 6 farklı değerlendirme kriteri belirlenmiştir. Sistemler kullandıkları ışık türüne göre direkt ve yayınık olarak ikiye ayrılmış ve belirlenen kriterlerin değerlendirildiği her iki ışık türü içinde ayrı çizelge oluşturulmuştur. Çizelge 1 ve Çizelge 2 üzerinde görülebileceği üzere sistemler iklim ve uygulandıkları konuma bağlı olarak gösterdikleri davranış performanslarına göre 'İyi-Normal-Kötü' şeklinde 3 farklı derecede değerlendirilmiştir.

\section{Bulgular ve Tartışma}

\subsection{Gün Işığı ve Mimari Tasarım Illişkisi}

Güneş, dünya üzerinde yaşayan bütün canlı ve cansız varlıklar için doğal aydınlatma ve enerji kaynağıdır. Yenilenebilir bir enerji kaynağı olması nedeniyle ihtiyaç duyulan enerjinin karşılanması, fosil kaynak kullanımının azaltııması ve çevre dostu bir enerji kaynağı olması bakımından önemlidir. Gün ışığı, direkt ışınım (güneş ışığı) ve yaygın ışınım (gök ışığı) toplamını ifade eder. Direk ışınım adından da anlaşılacağı üzere, doğrudan güneşten gelen ışınımdır. Güneşten yeryüzüne gelen direkt ışınım şiddeti geliş açısına bağıı olarak sürekli değişim gösterir. Öğle vaktinde gelen direkt ışınımlar en yüksek değere ulaşırken gün doğumu ve batımında gelen ışınımlar düşük açıyla gelmelerinden dolayı fazla yansımaya uğrayıp şiddetini yitirmektedir. Yaygın ışııım ise, tüm gök küreden gelen belirli bir doğrultusu ve yönü bulunmayan ışınımdır. Atmosferden giriş yapan güneş ışığının atmosferi oluşturan bileşenler, su buharı, toz ve havadaki moleküller tarafından saçılması veya yutulması ile yaygın ışınım oluşur (Okutan, 2008). 
Gün ışığı, yeryüzündeki canlı varlıklara hayat veren ışınımlardır. Işığın maddesel olarak özel bir yapıda olduğu kabul edilir ve hem dalga hem de parçacık özelliği göstermektedir. Hem dalga hem de parçacık özelliği gösteren ışık; boşlukta $300.000 \mathrm{~km} / \mathrm{sn}$ hızla yol alan, foton adı verilen parçacıklardan oluşan ve insan gözünün algılayabildiği elektromanyetik ışınımlardır. Elektromanyetik ışınım, elektromanyetik dalgalar şeklinde yayılan bir tür enerjidir. İnsan gözü tarafından algılanabilen görünür ışık, elektromanyetik dalga boyunun ve elektromanyetik tayfın bir parçasıdır (Moayed, 2011).

İnsan, gözüyle ışık kaynaklarını algılayabilmektedir. İnsan gözü 380nm-780nm dalga boyu aralığındaki elektromanyetik dalgaların cisimlerden yansıyarak gözümüze gelen ışınımlarıyla görebilmekte ve bu kısımlar renk olarak tanımlanmaktadır (Şekil 1).

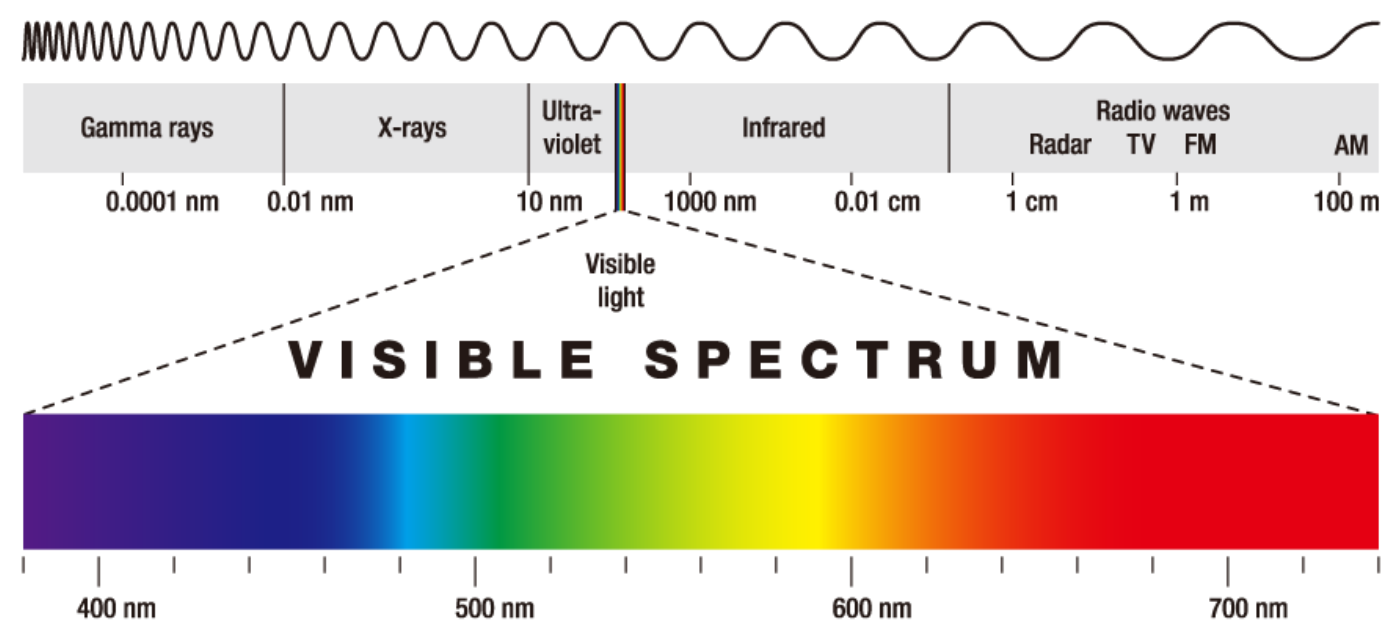

Şekil 1. Elektromanyetik tayf - dalga boyu gösterimi (Okutan, 2008)

Yüzyıllardır varlığını sürdüren güneş ışı̆̆ı yeryüzündeki en büyük doğal ısı ve ışık kaynağı olmuştur. Bu özelliği sebebiyle güneş ışığının farklı iklim tiplerinde oluşturduğu yararlı etkilerden faydalanmak, zararlı etkilerden korunmak amacıyla tasarımcılar gereken önlemleri almışlardır.

Gün ışığı ile aydınlatmada; iklim, gök koşulları ve bulunulan enlem gibi dış çevresel faktörlerin yanı sıra; gün ışığının iç mekâna ulaşmasında, mekân içerisindeki dağılımında belirleyici olan binanın yönlendirilmesi, binanın geometrisi, günışığı stratejileri, güneş kontrol elemanlarının biçimsel ve malzeme özellikleri ile ışık geçiren yüzeylerin biçimi, konumu ve ışık geçirgenlik özellikleri önemli parametrelerdendir.

Insanoğlu yaşam süreci boyunca barınma ihtiyacını karşılamak ve doğada kendine zarar verebilecek çevresel etkilerden kendisini korumak için farklı yapılar kullanmıştır. Mağara ve ağaç kovukları ile başlayan bu süreç insanın farklı teknikler öğrenmesi ve teknolojinin de gelişimi ile günümüzdeki halini almıştır. Bu süreç içerisinde gelişen yapım teknikleri ve barınma ihtiyacını karşılamak için kullanılan konutlarda pencere boşluğunun kullanılması ile güneş ışığı yapıların içerisine girebilmiş ve hem ısınma hem de aydınlatma kaynağı olarak kullanılmaya başlanmıştır. Yapı kabuğu üzerinde açılan pencere boşluğu sayesinde güneş ışığının yapı içerisine alınmaya başlanması ile gün ışığı odaklı tasarım gelişmeye başlamış ve iklim tipine göre binanın bulunduğu konum, bina yönlenmesi ve bina geometrisi istenilen özellikleri sağlayacak şeklide tasarımlar hayata geçirilmiştir (Phillips ve Gardner, 2012).

Sıcak iklim tiplerinde gün ışığı ile aydınlatma sağlanması istenirken, güneş ışığının oluşturduğu ısınma etkisinden kaçınmak için binaların yaşam alanı olarak adlandırdığımız hacimleri direkt güneş ışığını almayacak şekilde yerleştirilmiştir. Yine ısınmayı azaltmak ve soğutma yükünü düşürmek için binalar birbirlerini gölgeleyecek şekilde konumlandırılarak ya da oluşturulan eyvan tarzı ek hacimler ile gölgeleme sağlanarak, rüzgârın etkin kullanılması ve ısıl konfor şartlarını oluşturulması amaçlanmıştır. Aynı şekilde direkt güneş ışı̆̆ından korunmak ve yapay ışık kaynağı olmamasından dolayı gün ışığı ile aydınlatmanın sağlanması adına kuzey cephelerin saydamlık oranı yükseltilmiş ve oluşturulan bina geometrisi ile iç hacimlerin gün ışığı ile maksimum oranda aydınlatılması istenmiştir. Sıcak-kuru iklim tipinde tasarlanan avlu daha geniş boyutlarda oluşturulmuştur. Bu büyüklükte tasarlanan avlular daha 
fazla günışığı kullanımına olanak tanımaktadır. Bu durum aynı zamanda yüksek radyasyon kazanımına sebep olabilmektedir. Bu durumu dengelemek için avlular içerinde havuzlar oluşturmak önemlidir. Avlu içerisinde oluşturulan havuzlar ile sıcak ikliminde ihtiyaç duyulan nem ihtiyacı karşılanmaya çalışılmıştır. Avlu içerisindeki yapıların belirli saatler aralığında birbirine gölgeleme yapması amaçlanmıştır. Aynı zamanda avlu içerisinde tasarlanan havuzun yansıtıcı yüzey olarak kullanıldığı ve güneş ışınlarının istenilen şekilde yönlendirildiği tasarımlar oluşturulmuştur (Salur, 2016).

Soğuk iklim tiplerinde ise kuzey yarım kürede bina tasarımında oluşturulan bina geometrisi ile rüzgâra karşı korunma sağlanması, Isı transfer yüzeylerinin azaltılması istenmiştir. Güneş ışığından kazanılan ısı enerjisini maksimum düzeye çıkarmak adına yapılara güneye yönlendirilmiş ve güney cephede saydamlık yüzeyi arttııımıştır. Isı tutma kapasitesi yüksek malzemeler kullanılarak ısısal konfor şartları sağlanmıştır. İhtiyaç duyulan doğal aydınlatmanın sağlanması için güney cephede oluşturulan saydam yüzeylerde gölgeleme elemanları kullanılarak direkt güneş ışınımının olumsuz etkilerinden korunmaya çalışılmış ve gün ışığı ile aydınlatmadan faydalanılmıştır (Boubekri, 2008).

Ilıman iklim bölgelerinde ise bina yönelimi, konumlandırılması ve geometrisi her iki koşula da uyum gösterecek şekilde tasarlanmıştır. Mevsim (yaz ve kış) şartlarına uygun olacak şeklide, pasif sistemler tasarlanmış ve güneş ışığından mevsimsel ihtiyaçlar doğrultusunda faydalanılmak istenmiştir. Örneğin antik yunan uygarlığına ait konut girişlerinde kullanılan saçaklar ile yazın yüksek açıyla gelen direkt güneş ışınlarından korunma sağlar ve gün ışığı ile aydınlatma için kullanırken kış mevsiminde düşük açıyla gelen güneş ışınları mekânın derinliklerine ulaşır ve hem ısınma hem de aydınlatma ihtiyacı karşılamış olur (Boubekri, 2008).

İklimsel etkenlerin dışında gün ışığının mimaride farklı amaçlarla kullanıldığını da görmekteyiz. Gotik dönemde yapılan kiliselerde oluşturulan vitray camlarla gün ışığı hacmin içine alınır. Vitray camlardan alınan gün ışığının farklı renk tonlarında hacme gelmesi, hem mekân içerisindeki sivri kemerler ve kaburga tonozların görsel etkisini hem de kilise içerisinde istenilen renkli ve gizemli havasının oluşmasına yardımcı olmaktadır (Moayed, 2011).

Günümüzde teknolojinin gelişme göstermesiyle geleneksel tasarım yöntemlerinin ihtiyaç duyduğu gereksinimler kolaylıkla sağlanabilmektedir. Bu ihtiyaçlardan biri ve tasarımın önemli bir ögesi olan gün ışığının mimaride kullanımı günümüz şartlarında da önemini korumaktadır. Günümüzde binalarda iç hacimlerin ihtiyacı olan gün ışığının sağlanmasında tasarım sırasında alınan kararlara ek olarak gün ışığı yönlendirme sistemlerinin kullanıldığı görülmektedir.

\subsection{Gün Işığı Yönlendirme Sistemleri}

19. yy da yapay aydınlatma kaynaklarının gelişimi ve devam eden süreçte kullanım oranının artmasıyla beraber gün ışığı kullanımını inmal edilmeye başlandığı görülmüştür. Gün ışığı, 20.yy sonlarına doğru çıkan enerji krizi ve enerji ihtiyacının karşılanmasında kullanılan doğal kaynakların hızlı şekilde tükenmesi sonucunda çevre ve insan sağlığına olan olumsuz etkileri, yenilenebilir enerji kaynaklarına olan ilginin artması ve kullanıcıların iyileştirilmiş aydınlatma kalitesi talep etmesi gibi nedenlerle aydınlatma konusunda tekrardan kullanılmaya başlanmıştır. Geleneksel mimaride gün ışığı kullanımını arttırmak amacıyla çağdaş çözümler olarak 'Gün Işığı Yönlendirme Sistemleri' oluşturulmuştur.

Geliştirilen ‘Gün Işığı Yönlendirme Sistemleri’nin hedefleri olarak:

- Kullanıcıların talepleri doğrultusunda teşvik edici iç mekânlar oluşturmak,

- İçeriye alınan gün ışığının nicelik ve nitelik olarak kullanıı ihtiyaçlarını karşılayacak yeterlilikte olmasını sağlamak,

- Gün ışığının ulaşamadığı hacimlere gün ışığını ulaştırarak iç mekânda yeterli ve homojen aydınlık düzeyi elde etmek,

- Yeterli seviyede gün ışığının içeri alınması sırasında oluşacak kamaşmanın engellenmesini sağlamak,

- Güneşli iklimlerdeki direkt gün ışığının içeri girmesini önleyerek gölgelemek ve ısısal konfor şartlarının oluşmasına yardımcı olmak,

- Aydınlatma enerjisi için harcanan enerji miktarını minimum seviyeye indirmek,

- Görsel konfor şartlarının oluşmasını sağlamak, 
- İklimsel etkilerden oluşabilecek aydınlatma olumsuzluklarını en aza indirgemek,

- Farklı işlevlerde kullanılan hacimlerde yeterli gün ışığı seviyesini oluşturmak gibi maddelerden bahsetmek mümkündür (IEA, 2010).

Gün ışığı yönlendiren sistemlerle ilgili bir tanımlama yapmamız gerekirse, ışık kaynağı olarak pencerelerden veya tepe ışıklıklarından gelen gün ışığının kullanıldığı genellikle pencere veya tepe pencerelerinden gelen gün ışığı seviyesinin düzenlenmesi, iç hacimlere doğru yönlendirilmesi ve sıcaklık kontrolü (gölgeleme) amacıyla kullanılan sistemlerdir.

Güneş ışınımının iklimsel konfor üzerindeki etkisi ve saydam yüzeylerin güneş ışınımı karşısındaki performansları gün ışığı yönlendirme sistemleri ile hacimlerin aydınlatılması sağlar. Saydam yüzeyler aracılığıyla iç ve dış ortam arasında kesintisiz bir bağ oluşturulmasıyla beraber iç mekâna gün ışığının iletilmesini sağlanır (Kutlu, 2019).

\subsubsection{Işık rafı}

Işık rafı, gün ışığını hacmin derinliklerine ulaştırmak ve istenmeyen açılarda gelen direkt gün ışığının hacmin içerisine girmesini engelleyerek gölgeleme yapmak amacıyla kullanılan gün ışığı yönlendirme sistemidir. Sistem, üst yüzeyi yansıtıcı malzeme ile kaplı olan rafın üzerine düşen güneş ışığının yansıtıcı yüzey vasıtası ile hacmin tavanına yansıtılması ve tavandan yansıyan ışığın iç hacmin gün ışığı almayan kısımlarına iletilmesi ile gün ışığı taşınması esasına dayanır. Şekil 2'de görülebileceği üzere ışık rafı, pencere yüzeyine döşemeden itibaren göz hizasından daha yüksek bir konuma yerleştirilmektedir. Bu yükseklikte konumlandırılması net bir manzara sağlar ve dış görüşü engellemez. Yüksekte konumlandırılan ışık raflarından alınan verimin arttırılması için kat yüksekliğinin arttırılması önerilmektedir (Yenidoğan, 2017).

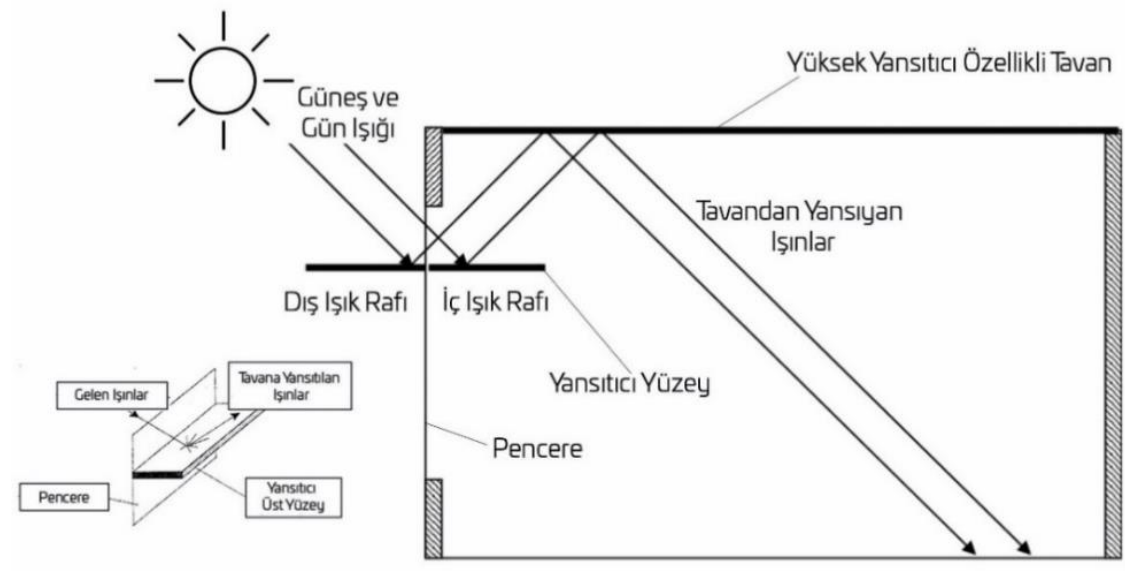

Şekil 2. Işık rafı çalışma prensibi (Erel, 2004)

Işık rafları pencere yakınındaki yüksek aydınlık düzeyini düşürerek oda içerisindeki en yüksek ve en düşük aydınlık düzeyi arasındaki farkı azaltır. Sistem bulunduğu konum nedeniyle pencereye yakın olan kısımlarda gölgeleme yapar ve özellikle yaz aylarında pencereye yakın kısımlarda oluşabilecek kamaşmayı engellemesi açısından önemlidir. Işık rafı, gün ışı̆̆ını tavana ve hacmin arka kısımlarına yansıtır. Tavandan yansıyan ışınlar gün ışığının hacmin derinliklerine taşınmasını sağlayarak hacmin derinliklerindeki aydınlık düzeyinin arttııımasına yardımcı olur. Pencere yakınındaki yüksek aydınlık düzeyinin azaltılması ve mekân derinliklerindeki aydınlık düzeyinin arttırılması ile ortamdaki aydınlık düzeyi farkı azalmakta ve bu da kullanıcı tarafından odanın daha iyi aydınlatılı̆̆ı hissini doğurmaktadır. Bu şekilde mekânda homojen bir aydınlatma oluşmasına yardımcı olur (Okutan, 2008 ; Erel, 2004).

Işık rafının konumu ve boyutu bulunduğu iklimsel bölge ve mevsimler baz alınarak gün ışığı ile aydınlatma ihtiyacına göre belirlenmelidir. Düşük enlemlerde hacmin içerisinde bulunan ışık rafının boyu gelen direkt güneş ışığını engelleyecek kadar uzatılabilir. Cephede bulunan ışık rafının en-boy gibi nicelikleri ise pencere yüzeyinin ne kadarı gölgelenmek isteniyorsa o oranda uzatılmasıyla sağlanır. Şekil 3'te görülebileceği üzere hareketli ışık rafı uygulamasında ise mevsimsel farklılıklardan 
oluşabilecek olumsuzlukların engellenmesi için ışık rafları belirli açılarda döndürülmelidir (Kurtay ve Esen 2019).

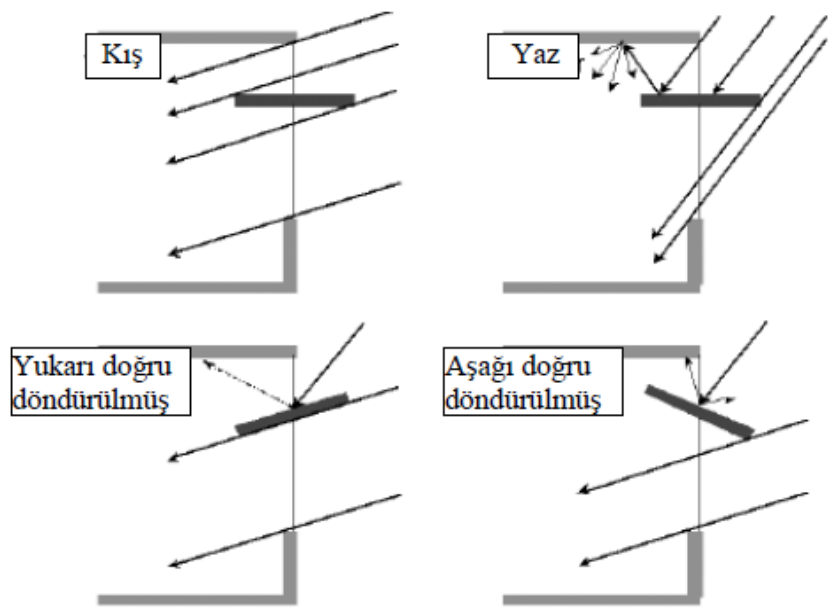

Şekil 3: Işık rafının mevsime göre uygulanması (Erel, 2004)

Işık rafı, direkt gün ışığının bol olduğu bölgelerde güneye yönlendirilmiş derin hacimli binalarda optimum performans göstermektedir. Doğu, batı yönleri ve kapalı gök koşullarının hâkim olduğu bölgelerde aynı derecede etkili olmamaktadır (Okutan, 2008).

Şekil 4'te Kanada'nın İngiliz Kolombiya'sı eyaletinde 1998 yılında yapımı tamamlanan 'SURREY Vergi Dairesi' beş katlı olup şaşırtmalı kat planı ile gün ışı̆̆ı kullanımını arttırmak istemiştir. Yapı tasarım fikri olarak çevre uzunluğunu maksimum düzeye çıkarılması ve içerisinde bulunan tüm ofis bölümlerinin gün ışığından faydalanması sağlanmaya çalışıımıştır. Gün ışığından fazla yaralanma düşüncesiyle bina doğu-batı doğrultusunda yerleştirilmiştir ve yapı kabuğundaki cam yüzeyler oranı yükseltilerek doğal ışık yapı içerisindeki kullanımı arttırılması amaçlanmıştır (Yenidoğan, 2017).
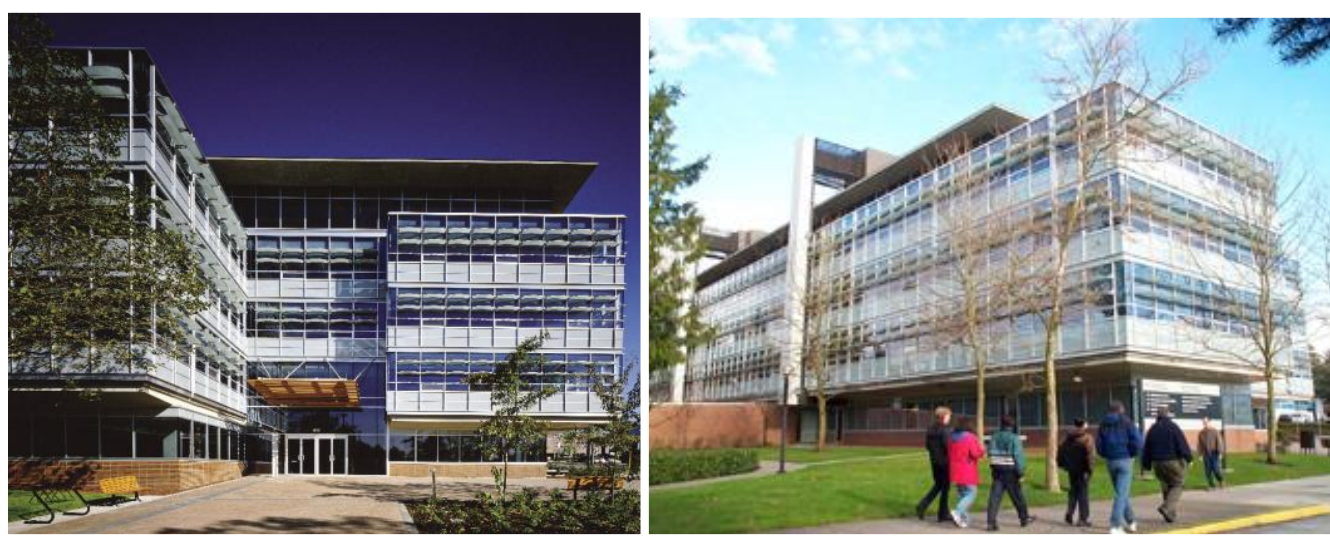

Şekil 4: SURREY vergi binası (Yenidoğan, 2017)

Çalışma alanlarında kullanılan geniş yüzeyli cam cephede uygulanan ışık rafı sistemi ile iç mekânlarda doğal ışığın geçişi sağlanmış ve sekiz metreye kadar olan hacmi derinliklerine kadar doğal ışığın yönlendirilmesini sağlanmıştır. Binada geniş pencereler ve yüksek tavanlar ile birlikte kullanılan ışık raflarının hem ısı kazanımını hem de aydınlatmayı düzenlediği görülmüştür (Şekil 5). 


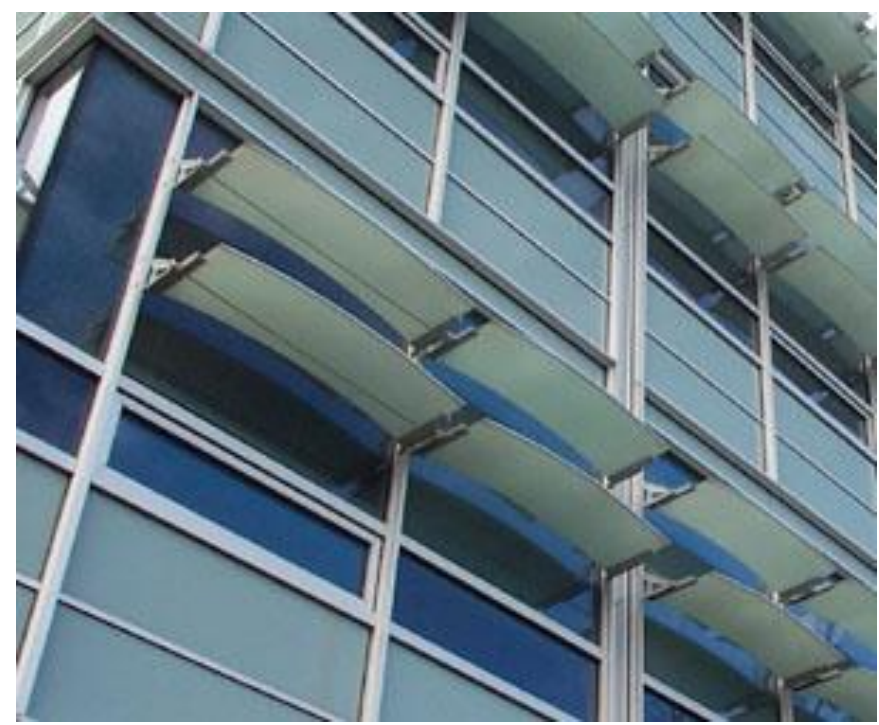

Şekil 5. SURREY vergi binası cephesi ışık rafı uygulaması (Yenidoğan, 2017)

\subsubsection{Anidolik sistemler}

Eski yunanca olan 'Anidolik' kelimesi görüntü oluşturmayan anlamına gelmektedir. Kapalı gök koşulları için geliştirilen anidolik sistemler optiğin teorilerini kullanarak tasarlanmıştır (Okutan, 2008).

Tasarlanan sistemlerde kullanılan yansıtıcılar anotlanmış alüminyum yüzeyler içerirler. Optik kontrolün sağlanması amacıyla değişik şekillerdeki çerçevelere yansıtıcı yüzeyler yerleştirilmiştir. Sistemin üst düzeyde performansını sağlayabilmek ve sistemi dış etkilerden koruyabilmek (temizlik ve bakım ihtiyacını) için gün ışınımının gireceği kanalların giriş ve çıkış yüzeyleri saydam, tam geçirgen malzemeler ile kaplanmıştır (Yenidoğan, 2017).

Anidolik sistemlerde kullanılan reflektörler sayesinde yüksek seçicilik sağlanır. Binalarda, direkt gelen gün ışığının hacme girmesini engellemek ve gökyüzündeki yayınık ışı̆̆ı hacmin derinliklerine taşınması için kullanılır. Yayınık gün ışığının kullanııması ile gün ışığından kaynaklanan kamaşmanın oluşmasını engellenir. Hacmin derinliklerine yönlendirilen gün ışığı ile düzgün bir aydınlatma sağlanmış olur.

Anidolik sistemler üç başlıkta incelenmektedir. Bunlar; anidolik tavan, anidolik açıklıklar ve anidolik petek sistemleri olmak üzeri üç başlıkta sınıflandırılabilir.

\subsubsection{Anidolik tavan}

Anidolik tavan sistemleri, kapalı gök koşullarının hâkim olduğu bölgeler içerisindeki binalarda, gökyüzündeki yayınık ışığını toplamak ve toplanan ışığın bir kanal vasıtasıyla hacmin derinliklerine yönlendirilmesi amacıyla kullanılır. Kapalı gök koşulları için geliştirilen sistem optiğin teorileri kullanılarak tasarlanmıştır. Bu sistem açık gök koşullarına sahip bölgelerde kullanılmak istendiğinde kamaşma ve ısınma sorunlarını engellemek için ek gölgeleme sistemlerine ihtiyaç duyulabilir (Okutan 2008).

Şekil 6'da şematik olarak gösterilen biçimde cephede bulunan toplayıcı özellikteki reflektör yayınık ışığı toplayarak ışık kanalına aktarır. İç yüzeyi yüksek yansıtıcı özelliğe sahip olan malzemelerle kaplı olan ışık kanalı, tam iç yansımalar yaparak kanala yönlendirilen ışığı kanalın sonunda bulunan parabolik dağıtıcıya iletir. Parabolik dağıtıcıya gelen yayınık ışık hacmin içerisine düzgün bir şekilde dağıtılır. 


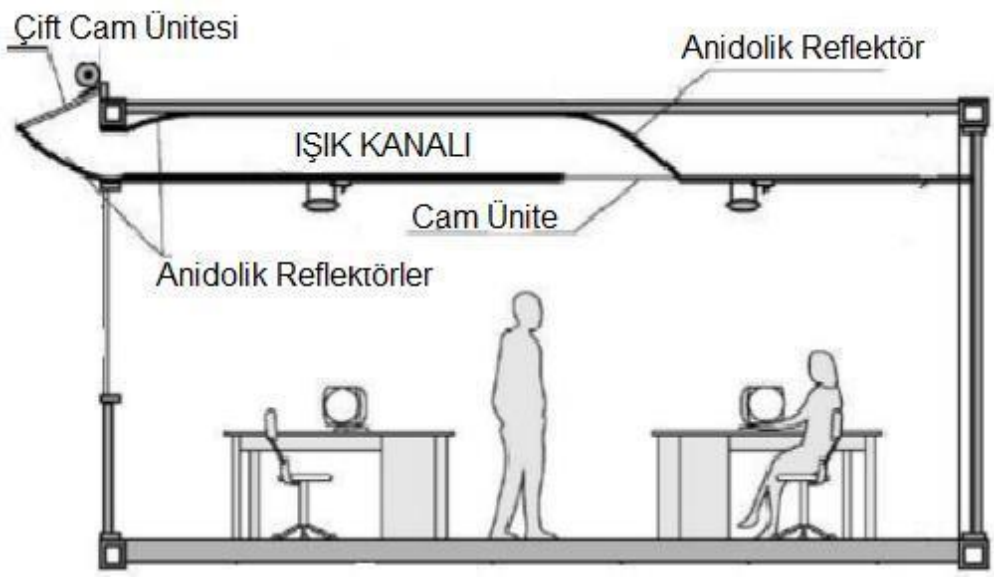

Şekil 6. Anidolik tavan sistemi (Ünal, Çetegen ve Enarun, 2005 )

Sistemin girişinde yatay düzlemle $25^{\circ}$ lik açı yapan cam bir ünite bulunur. Bu ünite üzerine gelen gün ışığını ışık kanalına yönlendirir. Işık kanalı boyunca iletilen ışık tavanda bulunan dağıııı ile hacme dağıtılır. Sistemin sağlıklı bir şekilde çalışmaya devam edebilmesi için hem sistem girişinde hem de çıkışında da bakım masraflarını azaltmak amacıyla saydam özellik gösteren bir ünite bulunur. Sistemdeki bütün harici parçalar yoğuşmayı ve ısıl köprüleri engellemek için yalıtılmışlardır (Ünal, Çetegen ve Enarun, 2005).

\subsubsection{Anidolik açıklık}

Gökyüzünde bulunan yayınık ışığı toplamak ve hacmin içine iletmek amacıyla oluşturulan sistem direkt gün ışığının hacme girmesini engeller. En verimli şekilde gün ışığından faydalanılması için güneşin hareket doğrultusuna uygun şekilde kuzey yarım kürede kuzey yönünde güney yarım kürede güney yönünde konumlandırılmalıdır. Bu şekilde optimum düzeyde yayınık gün ışığı toplanır.

Kuzeye bakan bütün açıklık sistemleri gibi bu sistemde bulut hareketlerine bağlı değişimlerden en az şekilde etkilenir. Bu şekilde kamaşma önlenir ve hacim içerisindeki görsel konfor artar. Görsel konforun sağlanması istenilen müzeler, atriumlar ve süpermarketler gibi yapılarda kullanışlıdırlar (Erel, 2004).

Şekil 7' de görüleceği üzere genellikle çatılara yerleştirilen toplayıcı ve dağıtıcı özelliklere sahip reflektörlerden oluşan sistemde girişte toplanan yayınık ışı̆̆ın yansıtma oranı yüksek yüzeylerden yansıtılarak dağıtıcı elemana gelmesi sağlanır. Dağıtıcı elemana gelen ışınlar oluşabilecek kamaşma ve herhangi bir geri yansıma engellenerek hacim içerisine yönlendirilir. Sistem içerisine yabancı maddelerin girmesini önlemek ve bakım masraflarını azaltmak için açıklık girişinde bir saydam özellikte koruyucu bir ünite bulunur (Okutan, 2008).

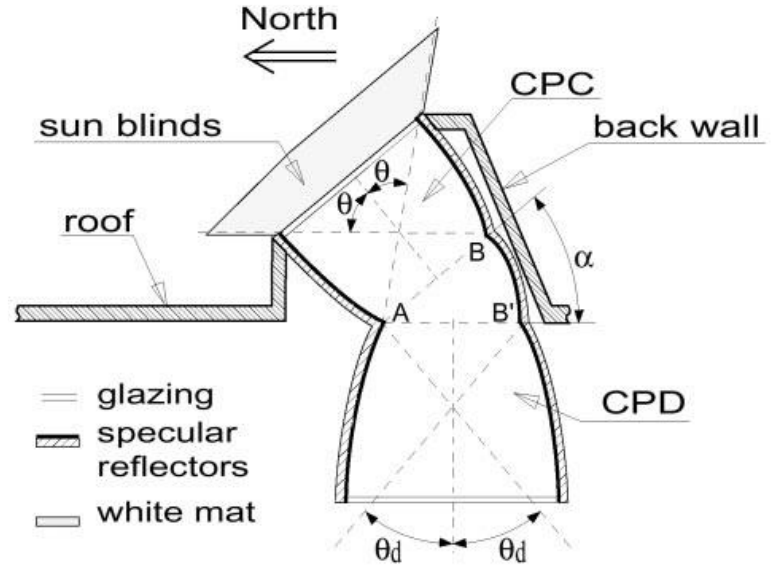

Şekil 7. Anidolik açıklık sistemi (Ünal, Çetegen ve Enarun, 2005)

\subsubsection{Anidolik petek}

Diğer anidolik sistemlere göre sunduğu yenilik küçük ve üç boyutlu yansıtıcı yüzeyleri olan elemanlara sahip olmasıdır. Optik elemanları cephe yönüne ve sıcaklık değişimlerine göre tasarlanabilir. 
Çoğunlukla açık gök koşulları için tasarlanmışlardır ve gün ışığını yönlendirmek için kullanılırlar. Gün ışığını yönlendirmesi sayesinde ısıtma ve soğutma yüklerinin azaltılmasında yardımcı oldukları görülür (Erel, 2004).

Şekil 8' de çalışma prensibi şematize edilen bu sistem, içi boş reflektörlerden oluşur. Her bir reflektörün içinde ikişer tane üç boyutlu parabolik yoğunlaştırıcı vardır. Parabolik yoğunlaştırııılardan ilki dışarıya yönlendirilmiştir ve yüksek eğim açılı ışığı geri yansıtırken, düşük eğim açılı ışığı sistem içine geçirir. İkinci yoğunlaştırıcı eleman ters yönde yerleştirilir ve yayınık ışı̆̆ı hacmin iç bölgelerine yönlendirmekle görevlidir. Kamaşmayı engellemek amacıyla ışık tavana doğru $25^{\circ}$ lik açıyla yönlendirilir (Okutan, 2008).

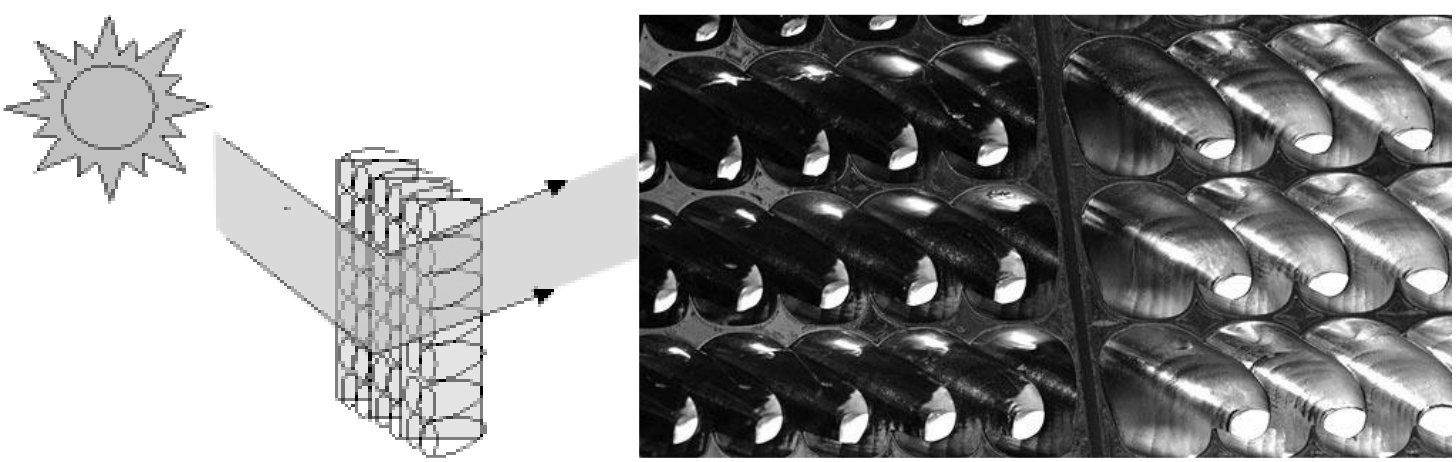

Şekil 8. Anidolik petek sistemi (Ünal, Çetegen ve Enarun, 2005)

Fransa'da 1988 yılında inşa edilen 'LESO Araştırma Binası' güneşe ait pasif enerji performansını inceleme ve izleme olanağı sunan araştırma lojmanıdır. Bu lojmanda firmalar üretmiş oldukları güneş enerjisi ile ilgili olan sistemleri uzmanlardan yardım da alarak uzmanların gözetiminde gerçek ölçeklerde test imkânı bulmaktadırlar. Şekil 9'da cephesi görülen lojman 1999 yılındaki geçirdiği yenileme sonrasında güney cephesinde anidolik sistem uygulanmıştır.

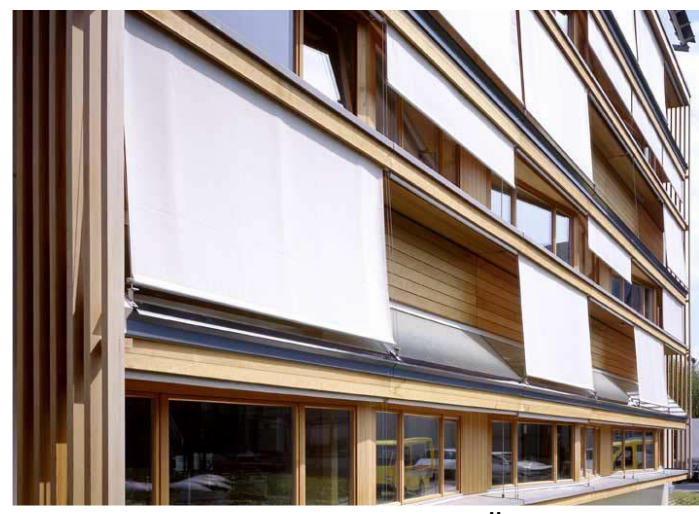

Şekil 9. Anidolik sistem örneği (Öztürk, 2006)

Uygulanan anidolik sistem uygulaması, bina içerisindeki fizik laboratuvarı için iyi bir deneme örneğidir. Şekil $10^{\prime}$ da cephe kesitinde görülebileceği gibi cephede uygulanan anidolik sistem sayesinde iç mekândaki parıltının önüne geçilerek yayınık halde bulunana ışığın mekânın derinliklerine iletilmesiyle beraber iç mekânda homojen bir aydınlık düzeyi oluştuğu gözlemlenmiştir (Öztürk, 2006). 


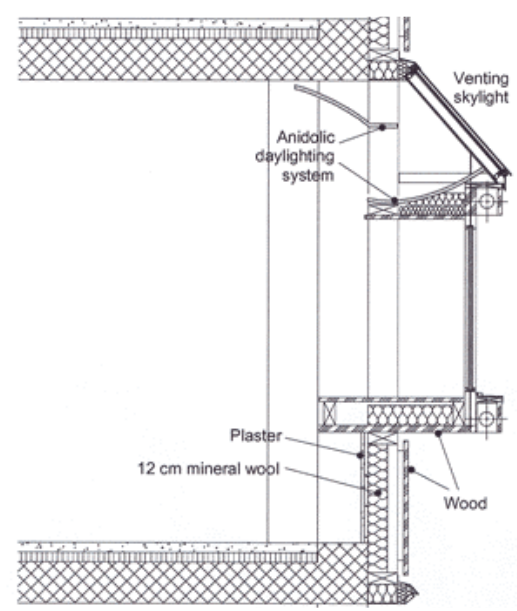

Şekil 10. Binanın dışından sistem kesiti (Öztürk, 2006)

\subsubsection{Prizmatik sistemler}

Prizmatik elemanlar, bir yüzeyi düz diğer yüzeyi prizmatik olarak yerleştirilmiş olan saydam materyallerden oluşur. Prizmatik elemanların dişlerinin konumları, prizma tipleri ve prizma dişleri üzerindeki açılar farklııı gösterebilir. $25 \mathrm{~cm}$ ya da $1 \mathrm{~cm}$ kalınlığındaki paneller veya $1 \mathrm{~mm}$ den daha ince esnek filmler panelleri halinde bulunabilir (Okutan, 2008).

Prizmatik paneller ışık raflarıyla beraber gün ışığı yönlendirmede kullanılan en eski sistemlerden biridir. Temel amacı yayınık gün ışığını hacmin derinliklerine ulaştırmaktır. Şekil 11'de de görülebileceği gibi sistemin optik özellikler sayesinde yayınık gök ışığı hacmin derinliklerine yönlendirirken aynı zamanda direkt gelen güneş ışığının da kontrol edilmesini sağlar. Prizmatik paneller, doğrudan gelen güneş ışığını iç mekâna yönlendirecek şekilde de kullanılabilirler. Bu durumda ışığın yansıması ve kırılmasından oluşabilecek parlama ve renk bozulmasını önlemek için uygun panel seçimine dikkat edilmesi gerekmektedir.
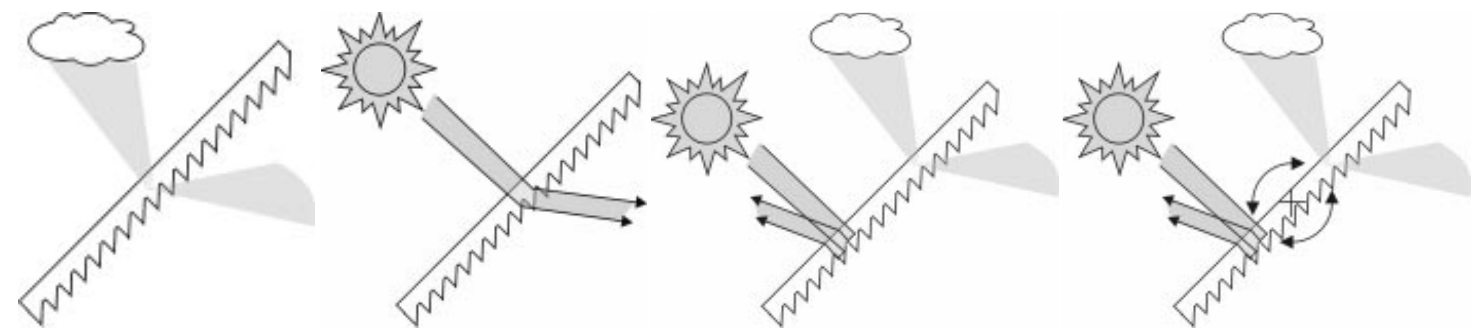

Şekil 11. Prizmatik panelin yaygın gün ışığı ve direkt gün ışığı ilişkisi (Sarıtaş, 2008)

Yönlendirilen gün ışı̆̆ının genellikle tavana ve hacmin derinliklerine doğru yönlendirilmesi ile oluşabilecek kamaşmanın engellenmesi amaçlanır. Prizmatik panellerin penceredeki görüşü etkilemesinden dolayı dış görüş ve manzaranın istenildiği yerlerde pencerenin üst kısımlarında kullanılmaları veya ek bir pencere açıklığı gerekmektedir.

Prizmatik paneller yaz mevsimi ve açık hava koşullarında, kış mevsimi ve kapalı hava koşullarına göre daha düzenli ve homojen bir gün ışığı dağılımı sağlamada başarılı oldukları gözlemlenmiştir (Kazanasmaz, Firat ve Tosun, 2011).

Prizmatik paneller gün ışığı stratejisine göre farklı yerlerde konumlandırımaktadırlar. Konumlandırıldığı yere göre dört farklı prizmatik panel kullanımı yapılabilmektedir. Prizmatik panellerin; pencere üstüne yerleştirilen prizmatik paneller, pencere camının arasına yerleştirilen prizmatik paneller, pencere önüne veya arkasına yerleştirilen prizmatik paneller ve çatıya yerleştirilen prizmatik paneller şeklinde kullanımı görülmektedir.

Şekil 12'de perspektif görünüşü verilen İsviçre'nin Basel kentinde 1993 yılında yapımı tamamlanan 'SUVA Binası' cephesinde yapılan yenileme çalışması ile cephede güneş kontrolü sağlanması amacıyla şeffaf giydirme yapılmıştır. Oluşturulan cephe sistemi ile üç farklı unsur amaçlanmıştır. Bunlardan ilki akustik açıdan yapıya dışarıdan gelen seslerin soğurulması, ikincisi şeffafıı oranının arttırıması ile dış 
görüşün arttırılması, üçüncüsü ise oluşturulan geniş şeffaf yüzeylerin oluşturacağı olumsuz etkisi olan güneş ışınlarından kaynaklı fazla ısınma yükü ve kamaşmanın engellenmesidir.
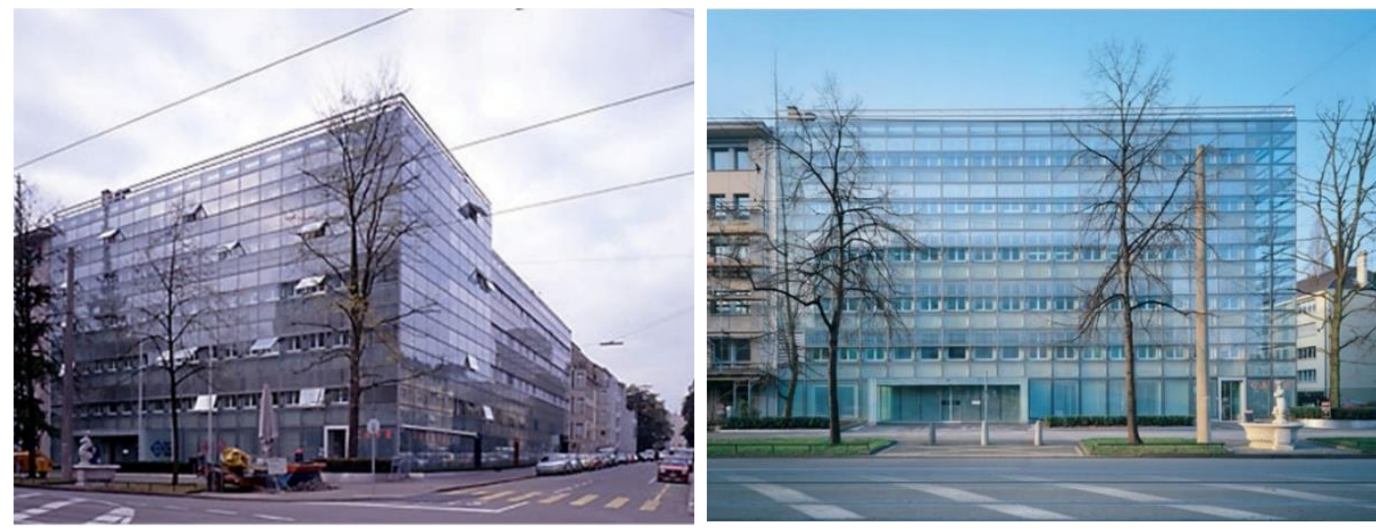

Şekil 12. SUVA binası ön cephesi (Seas Harvard, 2020)

Şekil 13'ten anlaşılabileceği gibi üçüncü unsurun sağlanabilmesi için cephede çift cam arasında kullanılan prizmatik panellerden oluşan bir sistem uygulanmıştır. Bu sistem dik ve dike yakın belirli açılarda gelen güneş ışınlarını geri yansıtırken bu açılar haricinde gelen ışınların mekânın içerisine geçişine izin verir. Böylece hem ısınma yükünde kontrol sağlanır hem de iç mekânda gün ışığının kontrollü kullanımı ile iç mekânın aydınlatması için gereken enerji miktarının azaltılmasına yardımcı olunmaktadır.
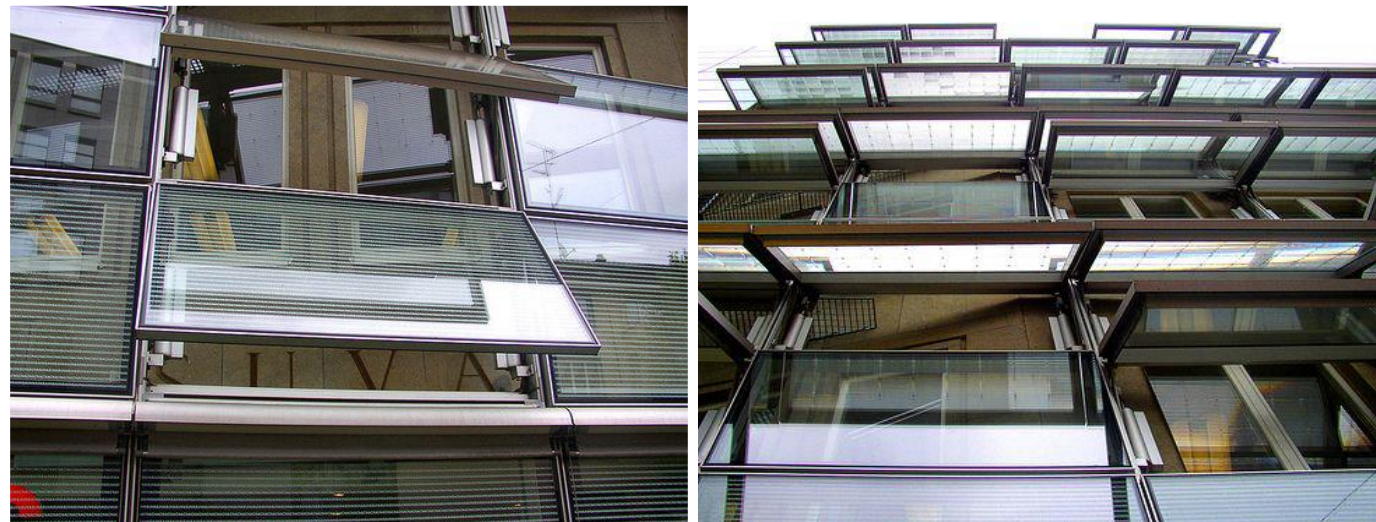

Şekil 13: SUVA binası çift cam arası prizmatik panel (Filters, 2020)

Katlarda bulunan paneller 1.70 m genişliğinde ve $1 \mathrm{~m}$ yüksekliğindedir. Camdaki bölümlerin her biri üç yatay sıradan oluşur ve her parça kendi basına hareket edebilecek şekilde tasarlanmıştır. Hareket eden paneller sayesinde güneşin açısal yüksekliğini elle ayarlanabilecek çift cam arasına yerleştirilen prizmatik panellerden oluşturulmuştur (Öztürk, 2006).

\subsubsection{Lazer Kesim Panel}

Saydam akrilik malzemeden yapılmış ince paneller üzerinde lazer yardımı ile lazer kesikleri oluşturulması ile üretilir. Belirli ölçüleri yoktur. Bu nedenle genellikle uygulanacakları yüzeye özel olarak üretilirler. Panel yüzeyinde oluşturulan her kesik bir ayna gibi davranarak oluşturulan paneli etkili bir ışık yönlendiricisi haline getirir. Çoğunlukla iki cam arasına yerleştirilen lazer kesim paneller kesik yüzeylerin lamine cam ile korunması koşulu ile pencere dışında da yerleştirilebilmektedir (Okutan, 2008).

Şekil 14'te şematize dildiği gibi lazer kesim paneller yüksek açıyla gelen ışınları geri yansıtırken düşük açıyla gelen ışınları kırma-yansıma-kırma işlemlerinden geçirilmesiyle iç mekâna alırlar. Kesiklerin ayna gibi davranmasıyla gelen ışınları hep aynı açıda yönlendirir. Bu nedenle sistemin verimi oldukça yüksektir. 


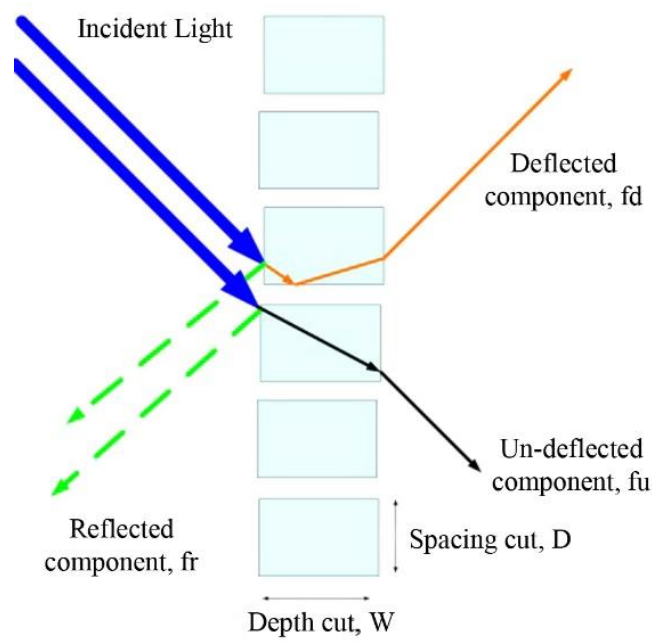

Şekil 14. Lazer kesim panel kesiti ve davranış şeması (Erel, 2004)

Kesik aralı̆ı̆ının kesik derinliğine oranı (D/W) 0.7 olan pencereye sabit olarak yerleştirilmiş bir lazer kesim panel $45^{\circ}$ ve üzerinde gelen açılarda hemen hemen tüm ışınları saptırır ve $20^{\circ}$ nin altından gelen açılardaki çoğu ışını da geçirir. Işığın büyük bölümü paneller vasıtasıyla tavana yansıtııı. Tavana yansıtılan ışık aynı ışık raflarında olduğu gibi, ikincil yaygın yansımış ışık kaynağı görevini yerine getirir (Erel, 2004).

Paneller uygulandıkları pencere yüzeyinde dış görüşü az miktarda olsa da engellemektedir. Gelen güneş ışınları tavana doğru yönlendirildiğinden kullanıcıda göz hizasında oluşabilecek kamaşmadan kaynaklanan rahatsızlık oluşturabilmektedir. Bunun engellenmesi lazer kesim panellerin pencerelerde göz hizasından yukarıda uygulanması önerilir (Kazanasmaz ve diğerleri, 2011).

Şekil 15'te görüldüğü üzere lazer kesim panellerin hareketli kanatçıklar şeklinde kullanılması durumunda mevsimsel etkilere (yaz/kış güneş gelme açısı) bağlı olarak güneş ışınlarının olumsuz etkileri engellenebilmektedir. Bu sayede istenmeyen güneşışınlarını yansıtarak gölgelemek ve gün ışığının yönlendirilerek hacmin derinliklerine taşımak mümkün olabilmektedir.

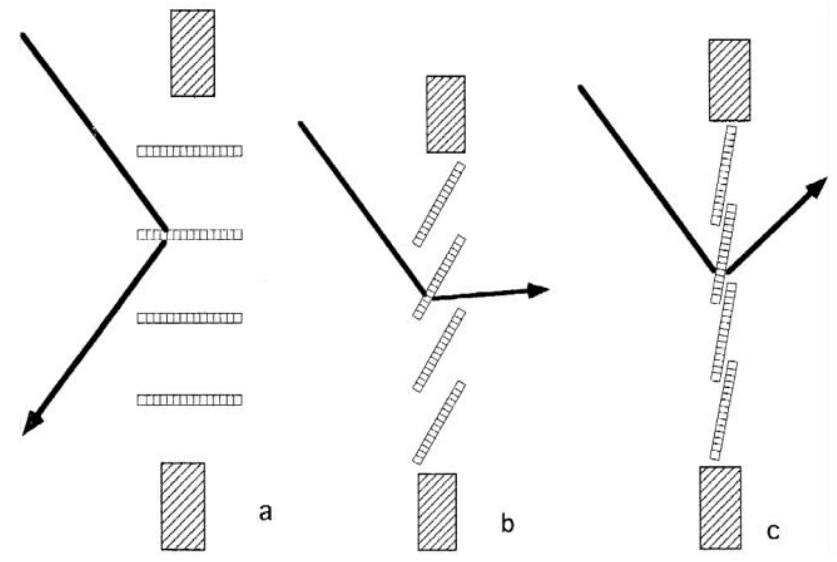

Şekil 15. Hareketli lazer kesim panel kesiti ve davranış şeması (Kazanasmaz ve diğerleri, 2011)

Kış şartlarında düşey duran paneller gelen ışınların iç mekâna iletilmesini sağlarken yaz koşullarında yatay duran paneller üzerine gelen ışınları yansıtarak iç mekânda gölgeleme sağlarlar. Benzer şeklide çatı ışıklıklarında kullanılan lazer kesim panellerde gün içerisinde gelen güneş ışınlarını geliş açısına göre iç mekâna iletir veya geri yansıtır. Böylelikle gün ışığını yönlendirilerek iç mekânda rahatsız edici olmayan bir aydınlatma sağlanmış olur.

Şekil 16'da Avustralya'nın Brisbane kentinde bulunan 'Kenmore South State' okulunda asma pencerelerin çift camlar arasına yerleştirilen lazer kesim panellerin kullanılmıştır. Lazer kesim paneller üzerine gelen gün ışığını hacmin tavanına yansıtarak mekân içerisindeki aydınlık düzeyinin arttırılmasına yardımcı olmuştur. 


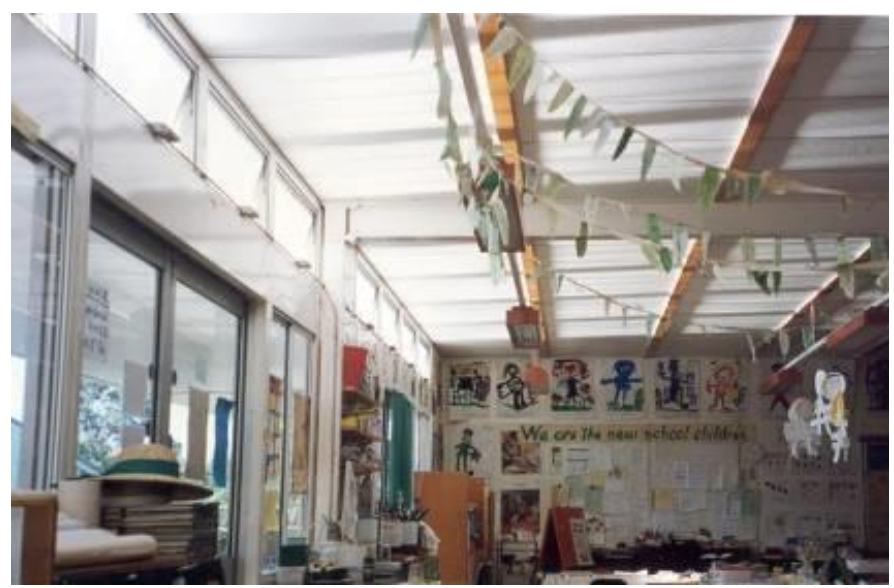

Şekil 16. Kenmore South State Okulu Brisbane/Avusturalya lazer kesim panel kullanımı (Solartan, 2020)

Alttaki kısımda bulunan pencere ve cam kapı dışardan bir veranda yardımı ile gölgelenir. Üst kısımda bulunana asma pencereler verandanın üzerinde kalır ve herhangi bir gölgelemeye maruz kalmazlar. Hem verandadan yansıyan ışınlar hem de direkt olarak asma pencerelere gelen gün ışığı lazer kesim panellerde kırılarak iç mekânın tavanına yönlendirilir. Bu şekilde gölgeleme elemanı bulunmayan asma pencerelerin iç mekânda oluşturacağı kamaşma ve parıltı etkisi giderilmiş olur. Böylelikle hem gölgeleme ihtiyacı giderilir hem de gün ışığı yönlendirilmesi ile aydınlatma sağlanmış olur (Solartan, 2020).

\subsubsection{Holografik optik elemanlar}

Temel bileşeni, iki cam panelin arasına lamine edilmiş holografik ızgaraların olduğu polimer film tabakasıdır (Okutan, 2008).

Holografik optik elemanlar çalışma prensibi olarak ışığın kırılma özelliğinden yararlanırlar. Bir kırılma ızgarası oluşturan ince mikroskobik çubuklar saydam bir film tabası üzerine basııır. Oluşturulan film tabakası çift cam arasına yerleştirilir. Izgaralar belirli açılardan gelen ışık ışınlarının yönlendirilmesine yönelik tasarlanabilir. Diğer doğrultulardan gelen ışınlar değişmeden kalırlar (Okutan, 2008) (Şekil 17).

Bu elemanlar eğer iyi tasarlanıp düzgün bir şekilde kurulursa ışığı odaklamak ve seçmek için kullanılabilirler. Böylece bina içindeki aydınlatma ve termal performansı istenilen seviyelerde tutabilirler. Işığın dalga boyuna göre seçici olabilme özelliği sayesinde direkt güneş ışınlarını da engellemekte kullanılabilmektedir. Bu özellikleri ile kapalı gök koşullarının hâkim olduğu bölgelerde, göğün tepe bölgesinden gelen yayınık ışı̆̆ın hacmin derinliklerine yönlendirilmesi için uygun bir sistem olarak görülmektedir. Sisteme direkt güneş ışı̆̆ı geldiği zaman renk bozulmasına neden olduğu için direkt güneş ışı̆̆ı almayacak şekilde cepheye yerleştirilmeleri gerekmektedir (Manav, Kutlu ve Küçükdoğu, 2009).

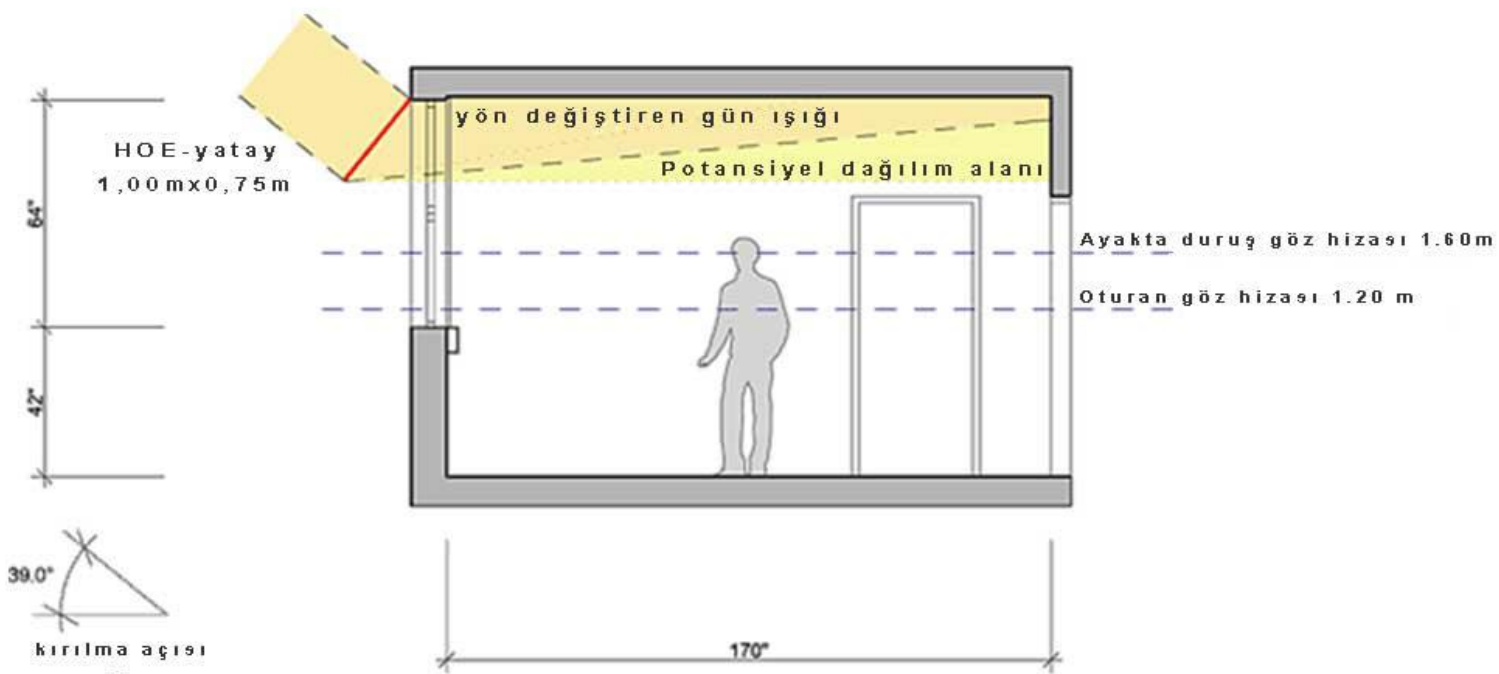

Şekil 17. Holografik optik eleman sistemleri ve gün ışığı yönlendirmesi (Okutan, 2008) 
Holografik optik elemanların iki cam panelin arasına koyulmasıyla oluşan sistem pencere dışına konumlandırılabildiğine değinmiştik. Bu şekilde konumlandırılan sistemlere 'Tepe Işığı Kılavuz Sistemleri' de denilmektedir. Tepe Işığı Kılavuz Camlarının tasarlanma amacı; yayınık gün ışığını odanı arka kısımlarına yönlendirerek odanın aydınlık düzeyi düşük olan kısımlarını aydınlatmak ve parıltı farklılığından kaynaklanan kamaşmayı azaltmaktır. Bu sistemler gün ışığını tavan doğru yönlendirirken dışarının görünmesini de engellememeyi hedeflemektedir (IEA, 2010; Apaydın, 2012).

Şekil 18' de Tepe ışığı kılavuz sistemi üzerine gelen belirli açılardaki güneş ışınlarını yansıtarak gölgeleme sağladığı gibi üzerine gelen gün ışığını hacim içerisine, tavana doğru dağıtarak hacmin derinliklerine gün ışığı iletimi sağladığı gösterilmektedir. Bu şekilde pencere yakınındaki aydınlanma seviyesinde düşüş olsa bile odanın iç kııımlarındaki gün ışığı faktörü artmış ve yaygın bir aydınlatma sağlanmıştır.

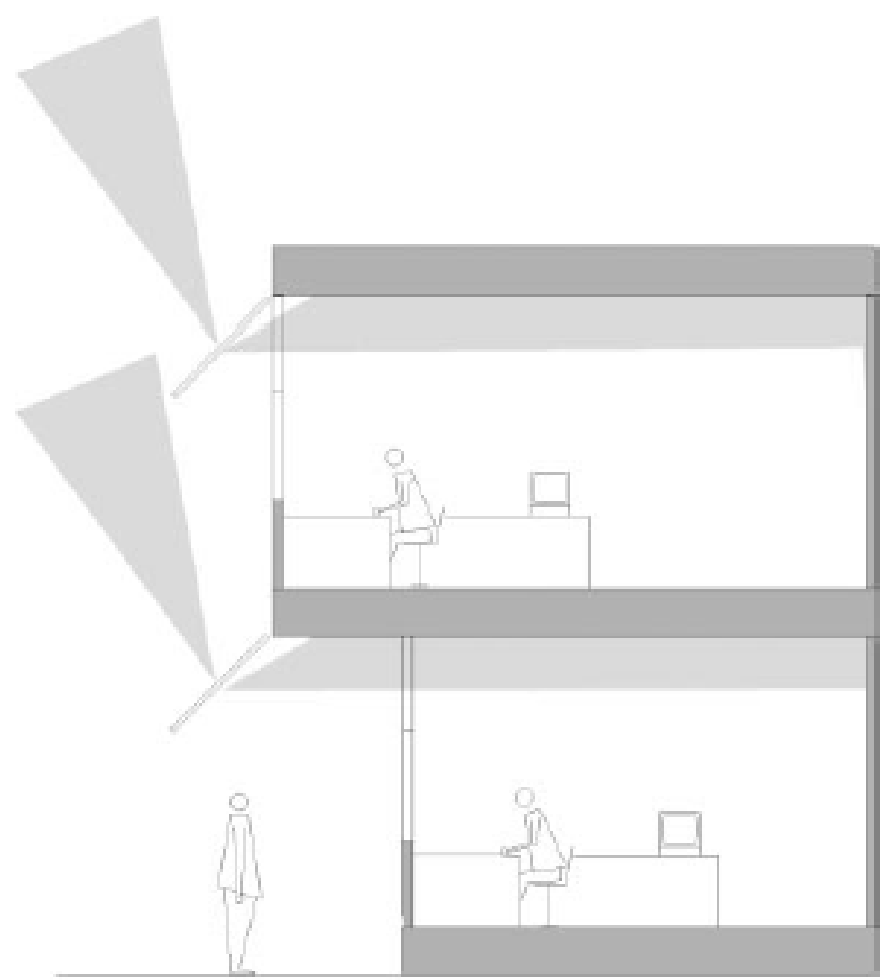

Şekil 18. Tepe ışığı kılavuzu kullanımı ile gün ışığının tavan ve hacmin derinliklerine taşınması (Erel, 2004)

\subsection{Gün Işığı Yönlendiren Sistemlerin Gösterdiği Davranışlar}

Sanayi devrimi ve sonrasında meydana gelen gelişmelere paralel bir şekilde yaşadığımız zaman dilimine kadar devam eden yenilenemeyen doğal enerji kaynakların hızla tüketilmesi, yenilenebilir enerji kaynaklarının en büyüğü olarak niteleyebileceğimiz güneş enerjisini ve bu enerjiden maksimum düzeyde faydalanmayı önemli hale getirmiştir. Dünya genelinde farklı ülkelerdeki kurumlar tarafından oluşturulan 'Bina Sertifikasyon Sistemleri 'de bu duruma kendi değerlendirme kriterleri içerisinde yer vermiştir. Güneş ışı̆̆ından faydalanmak, güneş ışııımlarını hem enerji kaynağı hem de aydınlatma kaynağı olarak bina tasarımlarına entegre edebilmesi ve kullanılması gibi konuları önemli başlıklar haline getirmişlerdir.

Gün ışığı yönlendirme sistemleri dışarıdan bakıldığında ilk yatırım maliyetlerini arttıran sistemler olarak görülmektedir ve aynı zamanda çoğunlukla sabit sistemler olmalarından dolayı uygulanmasının ardından yerlerinin değiştirilmesi masraflı olabilmektedir. Bu gibi dezavantajların engellenmesi oldukça kolaydır. Tasarım aşamasında gün ışığı kullanımı zor değildir fakat ön proje aşamasında ihtiyaçların iyi belirlemesi, maliyet ve enerji analizinin iyi yapılması, iklimsel ve fiziksel koşulları göz önüne alarak bina için en verimli sistemi seçmesi gibi birden fazla faktörün birbiri ile entegrasyonu hem tasarımcı hem yüklenici hem de kullanıcı açısından önemlidir. Kullanım ömürlerinin yüksek olması sebebiyle ilk yatırım maliyetini amorti edebilmesi ve kullanıcıya hem görsel hem de ısısal konfor sağlaması açısından öne çıkan sistemlerdir. 
Tasarımcıların tasarım aşamasında aldıkları kararlar ve bu kararların devamında yapılması planlanan bütün iyileştirmeler esasında kullanıc konforunu geliştirmek amacıyla yapılmaktadır. Yapı kabuğundaki boşluklar ve saydam yüzeyler aracılığıyla iç ve dış ortam arasında kesintisiz bağ kurularak iç mekâna gün ışığını alınmaktadır. Gün ışığı yönlendirme sistemleri, hacimler içerinde yeterli gün ışığı sağlanması ve hacim içerisindeki görsel konfor şartlarının oluşturulmasına yardımcı olurlar. Bu durum kullanıcılarda iç mekânda yeterli aydınlık düzeyi oluştuğu algısını uyandırır ve yapay aydınlatma kaynaklarına duyulan ihtiyacın azalmasına yardımcı olur. Böylece aydınlatma için ihtiyaç duyulan enerji miktarının minimuma indirilmesi amaçlanır. Gün ışığı yönlendirme istemleri iç mekânlardaki aydınlatma gereksiniminin karşılanmasını sağlamanın yanında oluşması muhtemel kamaşma ve fazla ısınma gibi olumsuz etkilerin önlenmesi amacı ile gölgeleme elemanı olarak da kullanılabilmektedir. Bu şekilde fazla ısınma oluşmasının önüne geçilerek ısısal konfor şartlarının sağlanmasına yardımcı olur.

Oluşturulan gün ışığı sistemlerinde, sistemlerin kullandıkları ışı türüne (direkt ve yayınık) göre farklı özellikler gösterdiği görülmektedir. Özelliklerinden yukarıdaki bölümlerde bahsettiğimiz gün ışığı yönlendirme sistemleri, farklı iklim tiplerinde farklı özellikler göstermektedir. Bazıları bütün iklim türlerinde kullanılacak sistemler olduğu gibi bazıları ise her iklim tipinde istenilen performansı gösterememektedir. Bundan dolayı gün ışı̆̆ı yönlendiren sistemlerin entegre edilmek istendiği tasarımlarda, yapının yapılması planlanan iklim bölgesinin incelenmesi, iklim bölgesinin özelliklerinin iyi kavranması ve yönlendirme sisteminden beklenilen davranışın tespit edilmesi gerekmektedir. İstenilen davranış özelliklerine sahip ve ihtiyaç duyulan gereksinimleri karşılayan sistemler arasından binanın bulunduğu veya konumlandırılacağı alanın iklimsel ve çevresel koşullarına en uygun olanın seçilmesi önemlidir.

Çizelge 1. Yayınık gün ışığı yönlendiren sistemler ve davranış özellikleri (IEA SHC, 2000)

\begin{tabular}{|c|c|c|c|c|c|c|c|c|c|c|}
\hline & \multirow[t]{2}{*}{ Görsel } & \multirow[t]{2}{*}{ Sistem } & \multirow[t]{2}{*}{ İklim } & \multirow[t]{2}{*}{ Uygulama Konumu } & \multicolumn{6}{|c|}{ Seçim Kriterleri } \\
\hline & & & & & 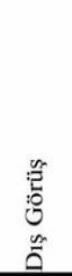 & 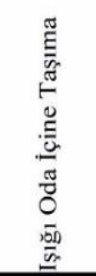 & 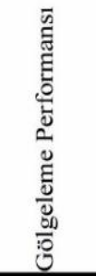 & 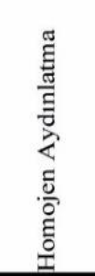 & 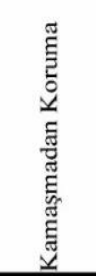 & 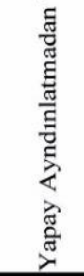 \\
\hline \multirow{7}{*}{ 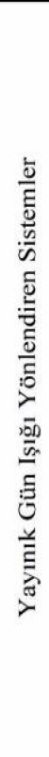 } & & Işık Rafi & $\begin{array}{l}\text { Ilıman İklim, } \\
\text { Bulutlu } \\
\text { Gökyüzü }\end{array}$ & Düşey Pencereler & Iyi & Normal & Normal & Iyi & Normal & lyi \\
\hline & & Andidolik Tavan & $\begin{array}{l}\text { Ilıman İklim, } \\
\text { Bulutlu } \\
\text { Gökyüzü }\end{array}$ & $\begin{array}{c}\text { Düșey Pencereler } \\
\text { Üzerinde Düsşey } \\
\text { Cephe Elemanı }\end{array}$ & İyi & İyi & Kötü & İyi & İyi & İyi \\
\hline & & Anidolik Tavan & Ilıman İklim & Tepe Işıılığı & İyi & İyi & Kötü & Iyi & İyi & İyi \\
\hline & & $\begin{array}{l}\text { Holografik Optik Elemanlar } \\
\text { (Zenit Açılılı) }\end{array}$ & $\begin{array}{c}\text { Ilıman İklim, } \\
\text { Bulutlu } \\
\text { Gökyüzü } \\
\end{array}$ & $\begin{array}{l}\text { Düşey Pencere, } \\
\text { Düsşey Cephe }\end{array}$ & İyi & Normal & Normal & Normal & Normal & Normal \\
\hline & & Prizmatik Sistemler & Her İklim & Düssey Pencereler & Kötü & Normal & İyi & İyi & İyi & Normal \\
\hline & & tik Sistemler- Çatı & Her İklim & Tepe Işı1klığı & Kötü & Normal & İi & Normal & İyi & Normal \\
\hline & & $\begin{array}{l}\text { Holografik Optik Elemanlar } \\
\text { (Saydam Gölgeleme Sistem) }\end{array}$ & Ilıman İ́klim & $\begin{array}{l}\text { Avluda Bulunan } \\
\text { Düşey Pencereler }\end{array}$ & Kötü & İyi & Normal & Normal & Normal & Normal \\
\hline
\end{tabular}


Çizelge 2. Direkt gün ışığı yönlendiren sistemler ve davranış özellikleri (IEA SHC, 2000)

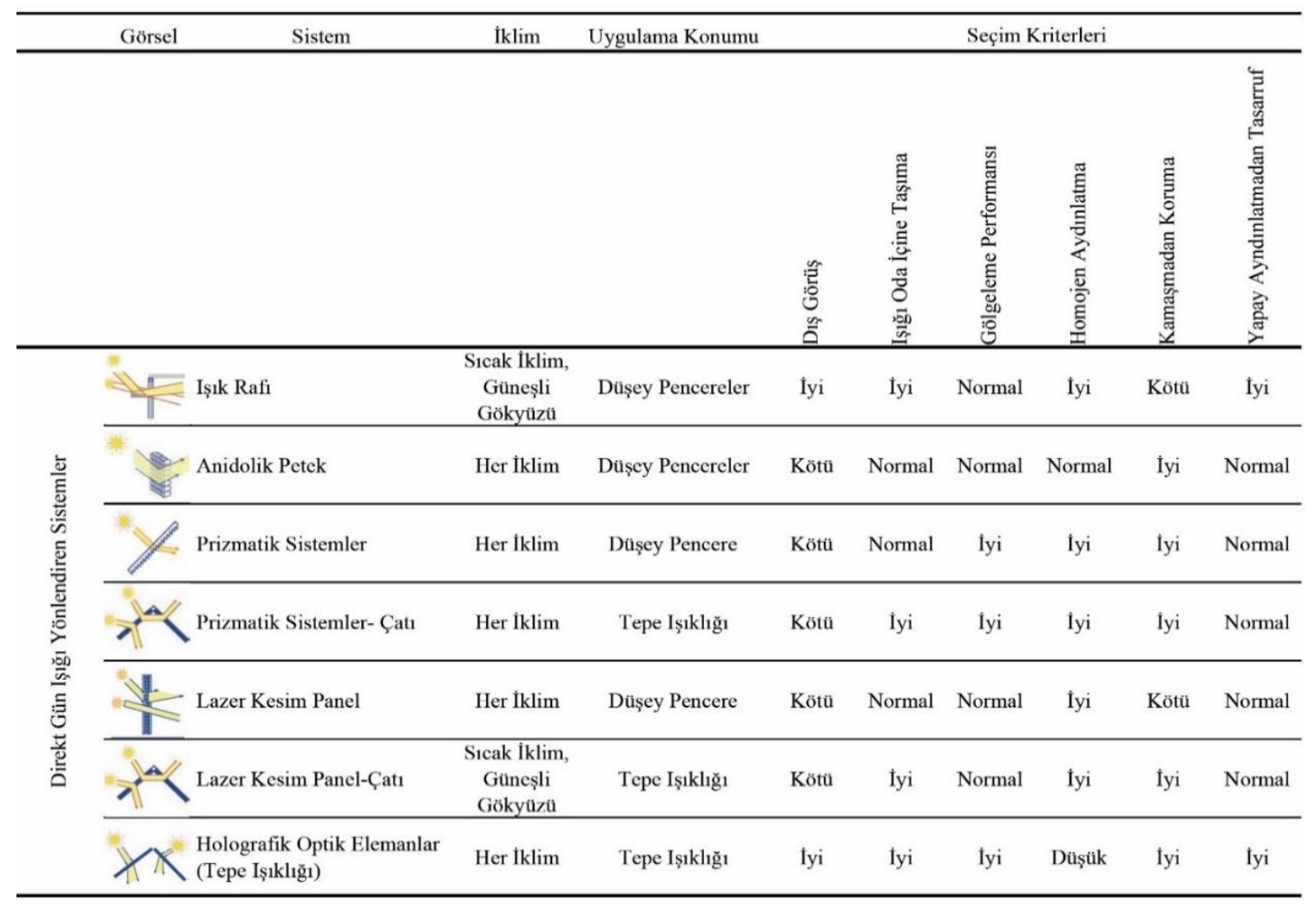

\section{Sonuç ve Değerlendirme}

Günlük yaşantımızda aydınlatma ihtiyacımızı çoğunlukla yapay aydınlatma elemanlarıyla karşıladığımız bilinen bir gerçektir. Enerji sarfiyatı üzerinde büyük etkisi bulunan yapay aydınlatmanın yerini yenilenebilir bir doğal enerji kaynağı olan gün ışığı aydınlatma sistemleri aracılığıyla karşılanması hem insanlar hem de yaşadığımız çevre açısından büyük katkılar sağlayacaktır.

Son 40-50 yıl içerisinde geliştirilmeye başlanan ve günümüzde hala üzerinde çalışılan gün ışı̆̆ı yönlendirme sistemleri gelişmiş ülkelerde yoğun talep görmektedir. Sürdürülebilirlik açısından yenilenebilir bir enerji kaynağı olan güneş ışınlarını kullanan aydınlatma sistemleri her geçen gün enerjiye talebin arttığı dünyada, bu talebin karşılanmasında fosil yakıtların kullanımını azaltması ve çevreye en az miktarda zarar vermesi açısından önemlidir.

Zaman içerisinde kullanıcıların bilinçlenmesi ve yeşil ürün sertifikalı ürünlere yönelmeleri üreticileri bu konularda ar-ge çalışması yapmaya yönlendirmiştir. Sürdürülebilir enerji kaynaklarına olan bu yönelime paralel olarak bu konuda çalışma yapan sertifika program sayısı ve üretici firma sayısındaki artış belirgin olarak gözlemlenmektedir. Gelişmiş ülkelere nazaran ülkemizde son zamanlarda talep görmeye başlayan ve kullanım alanı bulan bu sistemler hem kullanıcı konforu hem de gerekli olan aydınlatma ihtiyacının karşılanması bakımından önemlidir.

Ülkelerin ilgili bakanlıklarının teşvikleri ve sertifika sistemleri ile beraber çalışan tasarımcıların katkıları ile gün ışığı aydınlatma sistemlerin kullanım oranı ilerleyen günlerde artacaktır. Böylelikle hem sürdürülebilir enerji kaynaklarının kullanımı açısından hem de hacimler içerisindeki görsel ve ısısal konfor şartlarının sağlanması açısından gün ışığı taşıma sistemleri kullanılması önem göstermektedir.

\section{Teşekkür ve Bilgi Notu}

Makalede, ulusal ve uluslararası araştırma ve yayın etiğine uyulmuştur. Çalışmada etik kurul izni gerekmemiştir.

\section{Kaynaklar}

Apaydın, S. (2012). Ofislerde Aydınlatma Tasarımının Sürdürülebilirlik Açısından Mekan Tasarımına Etkileri. (Yüksek Lisans Tezi).Haliç Üniversitesi, Fen Bilimleri Enstitüsü,ístanbul. 
Boubekri, M. (2008). Daylighting, Architecture and Heath. Building Design Strategies. Oxford: Architectural Press, Elsevier Publishers, UK.

Erel, B. (2004). Gün Işığı Ile Aydınlatma Alanında Geliştirilen Yeni Teknolojiler Hakkında Bir Araştırma. (Yüksek Lisans Tezi). İstanbul Teknik Üniversitesi, Fen Bilimleri Enstitüsü,İstanbul.

Filters (2020), Erişim Tarihi: 15.06.2020. SUVA Binası, Erişim Adresi: https://www.filt3rs.net/case/suvahdm-484

IEA SHC. (2000). Daylight in Buildings - a Source Book on Daylighting Systems and Components. s.4-78 Erişim Adresi(28.05.2020): https://facades.Ibl.gov/sites/default/files/Downloads/daylightingc4.pdf

IEA. (2010). Daylight in Buildings, Energy Conservation in Buildings and Community Systems Programme. $\quad$ s.4-33 Erişim Adresi: http://www.ieaebc.org/Data/publications/EBC_Annex_29_PSR.pdf\%0Awww.iea-shc.org

Kazanasmaz, T., Fırat. P. ve Tosun, M. (2011). Prizmatik ve Lazer Kesim Panellerin Doğal Aydınlatma Performansı Açısından Değerlendirilmesi" VI. Ulusal Aydınlatma Sempozyumu. Erişim Adresi (03.06.2020): http://www.emo.org.tr/ekler/f20239b3aebdc66_ek.pdf-

Kurtay, C. ve Esen, O. (2019). Ofis Yapıları İçin Işıı Rafı Tasarımında $30^{\circ}$ ve $45^{\circ}$ Enlemlerinde Optimum Verim Sağlanması İçin Bir Yöntem. Journal of the Faculty of Engineering and Architec.ture of Gazi University 34(2):835-43.

Kutlu, R. (2019). Bir Tasarım Öğesi Olarak Günışığı. TOJDAC 9(2):226-33. Erişim Adresi(23.05.2020): https://dergipark.org.tr/tr/download/article-file/685315

Manav B., Kutlu, R. ve Küçükdoğu, M. Ş. (2009). Mimaride Kullanılan Cam Türlerinin Aydınlatma Açısından Incelenmesi. V.Ulusal Aydınlatma Sempozyumu. Erişim Adresi (20.05.2020) : http://www.emo.org.tr/ekler/21654b2b0214ac5_ek.pdf

Moayed, M. (2011). İ̧ Mekan Tasariminda Gün Işığı Kullanımının Sürdürülebílir Tasarim Kriterleri."(Yüksek Lisans Tezi). Hacettepe Üniversitesi, Sosyal Bilimler Enstitüsü, Ankara.

Okutan, H. (2008). Gün Işığı Ile Aydinlatmanin Temel İlkeleri ve Gelişmiş Gün Işığı Aydinlatma Sistemleri. (Yüksek Lisans Tezi). Mimarsinan Güzel Sanatlar Üniversitesi, Fen Bilimleri Enstitüsü,İstanbul.

Öztürk, Ç. (2006). Gelişmiş Doğal Aydınlatma Sistemleri ve Uygulama Örnekleri. (Yüksek Lisans Tezi). Gazi Üniversitesi, Fen Bilimleri Enstitüsü,Ankara.

Phillips, D. ve Gardner, C. (2004). Daylighting: Natural Light in Architecture. Oxford : Architectural Press, Routledge Publishers, UK, 9-19.

Salur, H. (2016). Avlulu Yapılarda Termal Konfor Analizi: Kayseri Köşk Medrese Örneği. (Yüksek Lisans Tezi). Fen Bilimleri Enstitüsü,Kayseri.

Sarıtaş, N. (2008). Yapılarda Gün Işığı Denetiminde Cam Malzeme Kullanımının Değerlendirilmesi." (Yüksek Lisans Tezi). Mimarsinan Güzel Sanatlat Üniversitesi, Fen Bilimleri Enstitüsü,İstanbul.

Seas Harvard (2020). Erişim Tarihi: 19.05.2020SUVA Binası, Erişim Adresi: http://people.seas.harvard.edu/ jones/lab_arch/H_and_dM/translations/hdm_4/hdm_4.html

Solartan (2020). Erişim Tarihi: 20.06.2020. Lazer Kesim Panel, Erişim Adresi: http://www.solartran.com.au/lasercutpanel.htm

Uğurtan, A. (2007). Anadolu Medeniyetleri Müzesi Arasta Bölümü’nde Doğal Aydınlatma Alternatiflerinin Değerlendirilmesi ve Bir Sistem Önerisi. (Doktora Tezi). Gazi Üniversitesi, Fen Bilimleri Enstitüsü,Ankara.

Ünal, G., Çetegen, D. ve Enarun, D. (2005). Gelişmiş Aydınlatma Sistemleri. s.165-70. Erişim Adresi (12.05.2020) : https://www.emo.org.tr/ekler/60d060b946d6dd6_ek.pdf 
Yenidoğan, C. (2017). Gelişmiş Doğal Aydınlatma Sistemlerinin İç Mekanda Kullanımı Açısından İncelenmesi. (Yüksek Lisans Tezi) Mimarsinan Güzel Sanatlar Üniversitesi, Fen Bilimleri Enstitüsü, İstanbul. 